УДК: 616-084: 373.2(477)

Вронська Вікторія

старший викладач кафедри педагогіки, психології та корекційної освіти

Рівненського обласного інституту післядипломної педагогічної освіти

ORCID iD: 0000-0001-8603-9405

DOI : https://doi.org/10.35619/prap_rv.vi13.115

\title{
ІСТОРІЯ РОЗВИТКУ МЕДСЕСТРИНСТВА ТА УДОСКОНАЛЕННЯ ДІЯЛЬНОСТІ МЕДИЧНИХ СЕСТЕР ДОШКІЛЬНИХ НАВЧАЛЬНИХ ЗАКЛАДІВ
}

Анотація В статті висвітлено особливості забезпечення медичної допомоги у різний період - від моменту зародження християнства і до сьогодення. Проаналізовано особливості становлення медсестринства - переважним чином зверталася увага на формування професійних знань. Відкриття дошкільних навчальних закладів; місие медсестри в таких установах; значення їх діяльності та специфіка роботи. В результаті, можна зазначити, що для ефективної професійної діяльності медичних сестер дошкільних навчальних закладів, недостатньо лише мати гарну професійну підготовку. Необхідно мати сформовану психологічну компетентність. Адже, згідно проведених нами досліджень, специфіка роботи в дошкільних навчальних закладах, вимагає від медсестри інших фахових якостей. В освітньому закладі вищими будуть інші професійні вимоги (комунікативні навички, здатність до емпатії, організаційні уміння та ін.), ніж до медсестер лікувальних закладів. Крім того, автономний характер прачі вимагає у медичних сестер дошкільних навчальних закладів особистісного вдосконалення. 3 огляду на ие, крім медичних знань, медичні сестри дошкільних навчальних закладів повинні бути компетентними $i$ в психологічних питаннях. 3 иією метою, було створено Групу особистісного зростання $i$ з ними проводили заняття. Ми висвітлили результати сформованої психологічної компетентності медичних сестер дошкільних навчальних закладів та підтвердили їх за допомогою 16-факторного опитувальника Кеттелла.

Ключові слова: медсестринство, здоров'я, історія медсестринства, вихованиі, медичне обслуговування, дослідження, психологічна компетентність медичних сестер дошкільних навчальних закладів.

Постановка проблеми. Відколи існує людство - відтоді і медична допомога. Актуальним $є$ питання вивчення історії розвитку медсестринства вцілому та медсестринства в системі дошкільної освіти зокрема, адже діяльність медичних сестер дошкільних навчальних закладів має свою специфіку і відрізняється від діяльності медичних сестер лікувальних установ. Крім медичних знань, вони повинні володіти психологічною компетентністю. Адже іiі несформованість «... є причиною багатьох помилок і упущень у діяльності медпрацівників» (Віднічук, 2011, с. 135).

Аналіз останніх досліджень 3 проблеми. Історію розвитку медсестринства в Україні досліджували вітчизняні та зарубіжні науковці: Алтинбекова, Апшай, Вороненко, Губенко, Капустник, Лісовий, Мудрик, Ольховська, Смирнова, Шегедин, Шевченко.

Мета статті - вивчити, проаналізувати історію розвитку медсестринства; особливості становлення та специфіку діяльності медичних сестер дошкільних навчальних закладів (далі - ДНЗ).

Матеріали і методи дослідження: теоретичні - аналіз і систематизація історичних, науково-теоретичних джерел, порівняння та узагальнення наукової літератури 3 даної проблеми; емпіричних - інтерв'ю, 16-факторний опитувальник Кеттелла.

Виклад основного матеріалу. Завдяки археологічним пам'яткам можна зробити висновок як щодо розвитку культури так і медицини, починаючи з часів заселення Криму скіфами.

Випуск 13, 2019. Збірник наукових праць РДГУ 
Від початку християнства були перші сестри-жалібниці, вони допомагали в українських т.з. лікарнях, створених так як і подорожні доми при монастирях. Відомості про першу стаціонарну лікувальну установу в Київській Русі відносяться до Х ст. - іiї відкрила Княгиня Ольга і догляд за хворими здійснювали, переважним чином, жінки. У «Житії Феодосія Печерського» описано створену монастирську лікарню в Києві у 3-4 чверті XI ст. Першою жінкою-медиком була Євпраксія Мстиславівна - внучка Володимира Мономаха. Вона опублікувала трактат «Аліма» та «Мазі», в якому описані всі, відомі на той час, хвороби та способи їх лікування, не оминула і питань гігієни. Можна зробити висновок, що 3 $\mathrm{V}$ до XII ст. у світських сестринських общинах допомогу хворим надавали «служниці Божі», духовні сестри. В епоху середньовіччя в Україні ніяких медичних навчальних закладів не було, знання передавалися від батьків - дітям, або здобували при монастирях. Значну роль в історії розвитку медсестринства в Україні відіграли братства. На Західній Україні уже в II половині XVIII ст. поміщиця Яблонська у Львові відкрила курси. А 1 жовтня 1773 р. було створено акушерський колегіум. Відомості з історії розвитку сестринської справи наступні: (Указ Петра I; Підготовка сестер милосердя 3 монахинь (1844), Хрестовоздвиженська община сестер піклування про поранених і хворих (1854); роль медичних сестер у роки Кримської війни (1853-1856); підготовка кадрів середнього і молодшого медперсоналу у Лондоні (Найтінгел, 1855) - однак, здійснивши аналіз цієї підготовки, можна зробити висновок, що Найтінгел приділяла увагу психологічним чинникам в догляді за хворими і моральним якостям медичних сестер, але психологія не входила у розроблені нею навчальні програми.

В Україні в той час уже відкривалися великі медичні навчальні заклади - у 1815 р. в Харкові, в 1841 в Києві, а в 1900 р. в Одесі. Внесок у справу забезпечення медичної освіти жінок зробив Пирогов (1810-1881). Він, крім іншого, приділяв увагу освіті жінок (під час оборони Севастополя - сестри милосердя). Пізніше, «1872-1882 рр функціонували медичні курси для жінок при Петербурзькій медико-хірургічній академії. 1879p - відкрито жіночу фельдшерську школу у Москві, а 1882p - у Петербурзі. 1907 p. - засновано Російське товариство «Червоного Хреста» (Вронська, 2019, с.43]. Водночас, варто зазначити, що у Львові, ще раніше, а саме в 1895 р. завдяки фінансуванню організації Червоного Хреста було створено школу медичних сестер. Другий такий заклад - «Приватну школу догляду за хворими» було у тому ж таки Львові відкрито у 1937 році. Проаналізувавши особливості підготовки медичних сестер у XIX ст., варто зазначити, що питання налагодження взаємовідносин між медсестрою і хворим не бралися до уваги і не висвітлювалися. Проте, відношення до пацієнтів, як і раніше, було таким, що грунтується на християнських традиціях милосердя і співчуття. У 1917 р. з'явилися червоні сестри.

Від початку запровадження медсестринства вже минуло 160 років. Одним із напрямів роботи медичних сестер була робота в освітніх закладах, зокрема і в дитячих садках. У СРСР до 1959 року за дітьми віком 1-3 років вели спостереження, доглядали саме медсестри, адже онтогенез розвитку в цьому віці вимагає постійного спостереження за антропометричними показниками. Також неабиякої уваги медсестри вимагає організація харчування (складання меню; відбір і зберігання добових проб страв) на той момент дитячі ясла-садки були підпорядковані Міністерству охорони здоров'я. Варто взяти до уваги, що той час декретна відпустка у матерів була надто короткою - 112 днів. Через те, дитячих яслах-садках необхідно було організувати кваліфікований догляд за вихованцями. Закономірно, що в такому віці вкрай необхідним $є$ контроль і спостереження за немовлятами, який здійснюють медичні сестри. 3 трирічного віку, діти переходили до дитячих садків. 1959p. - відкриття ясел-садків, у яких могли перебувати діти від народження до семирічного віку. Медичних сестер почали приймати на роботу до дитячих садків підпорядкованих Міністерству освіти. Тоді розробили нову єдину програму виховання дітей переддошкільного і дошкільного віку. В свою чергу, діяльність медичних сестер ДНЗ здійснюється згідно з Порядком медичного обслуговування дітей у ДНЗ.

На початку 2010-их років ми розпочали здійснення інноваційної діяльності. У дослідженні взяли участь 43 медичні сестри ДНЗ Рівненського району. Віковий склад 
вибірки : медичні сестри ДНЗ віком до 30 років -11 учасниць; віком від 30 до 45 років - 18 учасниць ; понад 45 років - 14. Робота здійснювалася у рамках Тимчасового науководослідного колективу «Групи особистісного зростання» (далі - ТНДК), задля формування їх психологічної компетентності. Завдяки діяльності ТНДК в учасників сформовані комунікативні навички, рефлексивні, емпатійність, прояви асертивної поведінки, низька агресія, спостерігається особистісне та фахове зростання. Показники професійного зростання ми діагностували за допомогою 16-факторного опитувальника Кетелла.

У ході проведеної психодіагностики було виявлено позитивні зміни у розвитку особистісних рис, що вплинуло на поведінки при виконанні професійних завдань. Факторний аналіз дав змогу продіагностувати рівень сформованості необхідних психологічних якостей у медичних сестер ДНЗ. Завдяки участі у розвивальній програмі в учасників дослідження сформувався новий підхід до виконання своїх професійних обов'язків. Підвищилася мотивація до професійної діяльності, ідентифікація 3 професією, більше уваги медичні сестри ДНЗ приділяють самоосвіті - все це позитивно впливає на ефективність роботи, адже формується професійна культура, панує доброзичлива атмосфера, сприятливий мікроклімат, у роботі застосовується командний підхід. Запроваджують здоров'я, зберігаючі, оздоровчі технології, психотерапевтичні методи (арт-терапія, музикотерапія, казкотерапія, глинотерапія, піскова терапія тощо. Тому за час діяльності ТНДК стан здоров'я у вихованців ДНЗ Рівненського району покращився, про це свідчать результати спільних медичних оглядів дітей, моніторинг стану здоров'я, результати опитувань як завідувачів ДНЗ так і батьків вихованців. Специфіка діяльності, а саме, те, що вони працюють у дитячому колективі, переважно зі здоровими дітьми, акцентують увагу на профілактичній, санітарнопросвітницькій діяльності, вимагає розвитку у медсестер ДНЗ комунікативних, емпатійних навичок, важливими в їх діяльності є організаторські функції, а з врахуванням того, що медсестра ДНЗ, на відміну від медсестер лікувальних установ працює не під керівництвом лікаря, а автономно, то необхідним є самовладання в непередбаченій ситуації, емоційна стійкість, впевнена (асертивна) поведінка та інші складові психологічної компетентності.

Висновки та перспективи подальших досліджень. Можна зробити висновок, що питання підготовки медичних сестер, як працюють в дошкільних навчальних закладах не привернули належної уваги. Хоча, на етапі запровадження професії медсестри питання формування психологічної компетентності медичних сестер не обговорювалося, варто зазначити, що певного роду профпридатність враховувалася, і бралися до уваги ті риси, якими повинні володіти медичні сестри. Автором здійснено порівняльний аналіз і можна стверджувати, що завдяки проведеним засіданням Груп особистісного зростання, особливості взаємин медичних сестер і вихованців ДНЗ покращилися і вони впливають на результат оздоровчого, лікувального процесу у закладі. Для того, щоб ця взаємодія була успішною, медичній сестрі недостатньо лише медичних знань. Тому, варто враховувати специфіку діяльності медичних сестер ДНЗ та працювати над формуванням їх психологічної компетентності.

\section{СПИСОК ПОСИЛАНЬ}

Віднічук, М. А. (Ред.). (2011). Проблеми психологічної компетентності медичних сестер дошкільних навчальних закладів. Рівне: РОППО.

Вронська, В. М., (2019). Особливості психологічної компетентності медичної сестри дошкільного навчального закладу. Психологія: реальність і перспективи, 12, 41-45.

Вчення про хворобу. (2011). Регеда, М. С., Березнякова, А. І., Тищенко, І. Ю. Патологічна фізіологія (2-ге вид.). (с. 19-24). Львів: Магнолія.

Даценко І. І., Шегедин, М. Д. (2001). Історія медииини та медсестринства. Київ. Ротенберг, В. С., Бондаренко, С. М. (1989). Мозг. Обучение. Здоровье. Москва: Просвещение. Фоменко, А. П. (Ред.). (2011). Усе для медсестер ДНЗ. Харків: Основа.

\section{REFERENCES}

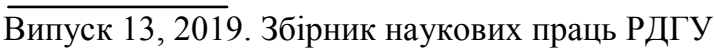


Vidnichuk, M. A. (Red.). (2011). Problemy psykholohichnoi kompetentnosti medychnykh sester doshkilnykh navchalnykh zakladiv [Problems of psychological competence of nurses in preschool institutions]. Rivne: ROIPPO. [in Ukrainian].

Vronska, V. M. (2019). Osoblyvosti psykholohichnoi kompetentnosti medychnoi sestry doshkilnoho navchalnoho zakladu [Features of psychological competence of a nurse of a preschool educational institution]. Psykholohiia: realnist i perspektyvy, 12, 41-45. [in Ukrainian].

Vchennia pro khvorobu [The doctrine of disease]. (2011). Reheda, M. S., Berezniakova, A. I., \& Tyshchenko, I. Iu. Patolohichna fiziolohiia (2-he vyd.). (s. 19-24). Lviv: Mahnoliia. [in Ukrainian].

Datsenko, I. I., \& Shehedyn, M. D. (2001). Istoriia medytsyny ta medsestrynstva [History of medicine and nursing]. Kyiv. [in Ukrainian].

Rotenberh, V. S., \& Bondarenko, S. M. (1989). Mozgh. Obuchenye. Zdorove [Brain. Training. Health]. Moskva: Prosveshchenye. [in Russian].

Fomenko, A. P. (Red.). (2011). Use dlia medsester DNZ [All for the DNS nurses]. Kharkiv: Osnova. [in Ukrainian].

\title{
HISTORY OF NURSING DEVELOPMENT AND IMPROVEMENT OF NURSING EDUCATION IN NURSING EDUCATION
}

\author{
Viktoria Vronska \\ Senior Lecturer of Rivne Regional \\ Institute of Postgraduate Teacher Education \\ ORCID iD 0000-0001-8603-9405 \\ DOI https://doi.org/10.35619/prap_rv.vi13.115
}

\begin{abstract}
At all times, the issue of maintaining and promoting health was of an urgent value. We have analyzed the peculiarities of providing medical care at different times - from the birth of Christianity to the present times. During the analysis, it became clear that the main focus was on the development of professional knowledge in nurses. We have studied in detail the features of nursing. The need for pre-school institutions; place of nursing in such institutions; importance of their activity and specificity of their work were also analysed. As a result, it can be noted that for the effective professional activity of nurses in pre-school institutions it is not enough to have good professional training. It is necessary to have a formed psychological competence. After all, according to our research, the specificity of work in pre-school educational institutions requires from the nurse other professional qualities. The educational institution will have higher professional requirements (communicative skills, empathy, organizational skills, etc.) than nurses in health care facilities. In addition, the autonomous nature of work (unlike pre-school institutions - in medical institutions, working under the direction of a doctor) requires personal improvement for nurses. For this reason, in addition to medical knowledge, nurses in preschool institutions should be competent in psychological aspects as well. To this end, a Personal Growth Group was established and, for five years, medical scientists, psychologists, both in the course and in the course of the course, conducted training with the nurses of pre-school educational institutions of Rivne district. We covered the results of the psychological competence of nurses in pre-school education and confirmed it using a 16-factor questionnaire by Kettell
\end{abstract}

Key words: nursing; health; history of nursing; pupils; medical care; research; psychological competence. 